\title{
Téoros
}

Revue de recherche en tourisme

\section{Innovations in Sustainable Tourism}

\section{Rachel Dodds}

Numéro hors-série, 2012

Innovations en tourisme durable

Innovations in Sustainable Tourism

URI : https://id.erudit.org/iderudit/1036563ar

DOI : https://doi.org/10.7202/1036563ar

Aller au sommaire du numéro

Éditeur(s)

Université du Québec à Montréal

ISSN

0712-8657 (imprimé)

1923-2705 (numérique)

Découvrir la revue

Citer cet article

Dodds, R. (2012). Innovations in Sustainable Tourism. Téoros, 55-58.

https://doi.org/10.7202/1036563ar

Ce document est protégé par la loi sur le droit d'auteur. L'utilisation des services d'Érudit (y compris la reproduction) est assujettie à sa politique d'utilisation que vous pouvez consulter en ligne.

https://apropos.erudit.org/fr/usagers/politique-dutilisation/
Cet article est diffusé et préservé par Érudit.

Érudit est un consortium interuniversitaire sans but lucratif composé de l’Université de Montréal, l'Université Laval et l'Université du Québec à Montréal. Il a pour mission la promotion et la valorisation de la recherche. https://www.erudit.org/fr/ 


\title{
Innovations in sustainable tourism
}

\author{
Rachel DODDS, Ph.D. \\ Associate Professor \\ Ted Rogers School of Hospitality and Tourism Management \\ Ryerson University \\ r2dodds@ryerson.ca
}

A significant number of destinations are dependant on tourism for their livelihood and tourism's contribution to national economies has grown year over year. Although many positive factors such as income, employment and overall economic development can be gained from tourism, many destinations have experienced significant degradation and there is no longer debate about the need to move towards more sustainable tourism in destinations. Although there is no shortage of literature about sustainable tourism, however, it seems that the global tourism industry still struggles to share this concept globally. This special edition of Téoros, therefore seeks to showcase innovations in sustainable tourism that are not only practiced but also illustrate knowledge transfer. The case studies in this publication describe different innovations that have been adopted in the tourism industry which help demonstrate the transformation towards sustainability and outline the learning that other destinations can benefit from.

\section{Examining Innovation}

On the most basic level, a consensus has been reached that an innovation consists of a creative new idea that is brought forth and applied to provide some type of business value (Sears and Baba, 2011; Yu and Hang, 2010). According to Carlsen et al. (2008: 3), innovation can be described as "a catalytic development process that activates a number of processes according to a new situation". It can take the form of a product, process, management, logistics or institutional innovation (Hjalager, 1996) and can be disruptive or an incremental process (Schaper and Volery, 2007).

Although much interest and research has been invested into the field of innovation due to its wide scope and significance in every industry, especially technology, even a standard definition of the term has yet to become accepted by the academic community (Yu and Hang, 2010; Markides, 2006; Sears and Baba, 2011; McElroy, 2006). The issues associated with innovation research are amplified in the tourism industry as the ambiguous definitions make it difficult to know which new ideas and concepts can be classified as innovations. For example, what some may classify as innovation, others may dismiss as an adaption of an existing idea or a recreation of something long past. This issue has lead Hjalager (2002) to claim that only large tourism corporations are capable of innovation because they are the only entities with enough power to alter the functionality of the industry as a whole. This claim would then exclude seemingly innovative developments in niche or tourism made by smaller businesses due to their size, however, smaller sized tourism entities can make revolutionary changes due to the nature of their development and ability to share knowledge through partnerships and education and should not be overlooked (Paskaleva-Shapira 2008; Andereck, 2009; McElroy, 2006).

Since innovative creative developments have many significant costs and benefits, it is important to understand both these aspects of the innovative process. Once benefits have been identified, they can then be classified in two ways. First, by their strategic importance into four categories of benefits: (1) implementation; (2) human partnership dynamics; (3) operational effectiveness; and (4) economic performance (O'Connor et al., 1990; Bunduchi et al., 2011) or second, into one of three categories based on whether they provide direct, indirect or relationship benefits (Weber and Kantamneni, 2002; Bunduchi et al., 2011).

Within tourism, innovation tends to be driven by external forces such as changing demographics, government policy, environmental changes or social issues, however, this is not always the case and innovation in tourism can be artistic or design based and improve the quality of service or visitor experience and are described as value innovations (Nankervis et al., 2005). 


\section{Innovation Developments in this Special Issue}

This special edition of Téoros seeks to illustrate that innovations can be found globally - from small islands, countries and states and in both developing and developed destinations. This special edition includes seven case studies that offer insight into elements of strategic importance as well as categories of benefits. Although each case study chosen illustrates in detail one or two particular elements needed for sustainability such as: partnership dynamics, capacity building, education and knowledge sharing, accessibility and benefit to wider stakeholders, evaluation and management (Bramwell and Lane 1993; Font and Ahjem, 1999; Liu, 2003; Berresford, 2004; Fadeeva, 2004; Kernel, 2005; Kelman, 2007; Dodds and McElroy, 2008; Williams and Ponsford, 2009; Lim and Cooper, 2009; Graci and Dodds, 2010), all encompass multiple elements of strategic importance showcasing implementation, economic implications, effective operations as well as partnership dynamics that allow for wider knowledge sharing across destinations. All the case studies in this issue also illustrate direct and indirect benefits and most importantly relationships that have been fostered due to these initiatives. The purpose of this special edition, in case study format, is therefore to emphasize the sustainability innovation that the destination undertook and explain how the practice benefited not only the destination in question but also how this success reached a wider audience outside the tourism visitors or the business that implemented them.

The case studies in this publication first introduce an issue within tourism, then set provide the research setting or destination background and short methodology. Subsequently, a discussion of the associated decisions and processes that were relevant to the dilemma or opportunity are highlighted followed by practical, specific outcomes on how the destination or association addressed the issue or problem and what aspect was innovative. Given the range of contributions, a number of themes have been identified that link to successes for sustainable tourism as mentioned above. As many case studies illustrate more than one element, each case study contributor was asked to focus on one particular element to avoid duplication of literature and instead focus on the approach and outcomes. Indeed, Hjalager et al. (2008: 33) considers innovation to be "new combinations, best fostered by dense networks of a variety of linkages". This publication seeks to disseminate innovation in organizations and destinations through an analysis and discussion framework.

Contributors were sourced from a joint French/English workshop held in Toronto in March 2012. They were both graduate students and academics who were doing research within tourism were invited to share their learnings and encouraged to produce a case study that would be relevant to an international audience. Contributors were asked to consider what issues were faced, what innovation helped overcome barriers to success and what processes or management frameworks were used to gain positive outcomes. Although the case studies were meant to be short (approximately 3000 words), authors were asked to provide a brief literature review to provide context as well as provide a descriptive analysis of what happened and the benefits gained which would be transferrable to other destinations. This issue of Téoros has also been produced in both French and English as little tourism literature is available bilingually and the purpose of this edition is to share knowledge widely and practically to both academics and practitioners working in tourism with the hopes that these practices will be shares and innovations duplicated.

\section{The Case studies}

The following case studies illustrate different benefits. First direct and indirect benefits are discussed through two smaller destinations case studies that focus on smaller communities. In the first article, Kelly MacKay and J. Michael Campbell's article about community tourism in Uganda focuses on capacity building and the need for local as well as national partnerships to assist the local people with sustainability of their operations and activities. The tented camps in Uganda illustrate that although small scale, economic performance can also benefit the wider community through a model of profit sharing and educational development. The innovation in this paper rests on a triangulated approach of education, community involvement, and strategic networks.

In the second article, Sonya Graci then showcases Moose Cree ecolodge in Canada to prove that direct and indirect benefits have come from tourism development and has led to improved community dynamics in addition to economic benefit. Community based tourism development in the case of this world-renowned ecolodge led to the empowerment of local people that ultimately results in sustainable livelihoods. As in the case of the Cree Village ecolodge, the community benefited from an increase in economic development in an otherwise impoverished area. Becoming self-sustaining reduced reliance on government assistance and preservation of cultural, heritage and the natural environment was gained by embracing pride and acceptance in the Mo'Creebec culture.

Next, two articles specifically focus on innovations in measurement and evaluation and operational efficiency in both the developing and developed world. In the third article, Lacey Willmott and Sonya Graci's article discuss Gili Trawangan, an island in Indonesia which exemplifies that effective implementation and multi-stakeholder partnerships benefits not only the businesses in a region but the wider destination as a whole and can lead to management systems not often seen in developing countries. Their article focuses on an often overlooked topic of solid waste management in tourism that has lead to environmental damage and aesthetic pollution, both which negatively impacts the tourist experience and host community. A network of strategic partnerships illustrate how a successful partnership has increased efficiency through the introduction of source separation and storage, which is essential for improving collection effectiveness and efficiency. One hundred percent of residents on the island now receive waste collection and there have also been improvements 
to the waste planning process. The innovation in this case study is that it engaged and facilitated dialogue between Indonesians and Westerners, creating cooperation that is necessary for a waste management system to succeed.

In the fourth article, Juste Rajaonson and Georges Tanguay illustrate how an international management and evaluation system can prove effective at a local level. Their article outlines Canada's Gaspésie and Isle de Madeline's evaluation of tourism using indicators and shows that global indicators can be managed and utilized at a local level without reducing their credibility. This innovative strategy allows identifying a parsimonious list of sustainable tourism indicators that are relevant, measurable and consistent with the tourism policy of each region. The outcome showcases how global scientific expertise was utilized at a local level to improve management effectiveness and transparency..

Bruno Sarrasin and Jonathan Tardif in the fifth article, then bring in a larger view of tourism management and asks if co-management could be analyzed as an innovative practice in promoting natural resources-oriented tourism. The Waitukubuli National Trail project carried out in Dominica is an example of a novel co-management practice for ecotourism-related resources. Local participation and involvement in planning tourism by multiple stakeholders have led to the development of tourism corridors between the segments of the trail and marginalized communities have therefore also benefited from tourism in addition to the plan being solely for ecological protection.

Rachel Dodds and Nicolas Berthet, in the last two articles, look at specific implementation that has resulted in both knowledge sharing and wider national benefits. Although external forces such as policy changes or demographic or environmental changes can affect a region, innovations that are regionally or nationally based have come out of potential negative circumstances. Nicolas Bertet discusses a successful policy implementation that has now been duplicated in other regions showing national benefits. Northern Cataluña's tourism board demonstrates that a sustainable transportation policy that is implemented thoughtfully, not only proves to perform economically but also helps decrease seasonality in a region and increases benefits to the wider community by increasing accessibility to the hinterland. The innovation was the tourism authority making protection and highlighting of the historical, cultural and natural heritage a priority.

Rachel Dodds's article about Chumbe Island in Tanzania showcases how, through partnerships, effective conservation and management has benefited the local communities as well as the overall country. Environmental education offered to both tourists and teachers and Tanzanian students have facilitated knowledge sharing that has been so successful, the educational framework is now used nationally.

\section{Summary}

These seven case studies have drawn examples from different regions of the world as well as different sized locations in both the developed and developing world. Despite their diversity in setting, each case study showcases innovations of strategic importance the four categories of benefits: (1) implementation; (2) human partnership dynamics; (3) operational effectiveness; and (4) economic performance. Direct, indirect and relationship benefits are illustrated and hopefully will assist knowledge transfer to increase sustainable tourism globally.

\section{References}

ANDERECK, Kathleen L. (2009) “Tourists' perceptions of environmentally responsible innovations at tourism businesses", Journal of Sustainable Tourism, vol. 17, $\mathrm{n}^{\circ} 4$, p. 489-499.

BERRESFORD, James (2004) “Tourism in the Region”, Regional Review Hearing, p. 1-11.

BRAMWELL, Bill and Bernard Lane (1993) "Sustainable tourism: An evolving global approach", Journal of Sustainable Tourism, vol. 1, n ${ }^{\circ}$ 1, p. 1-4.

BUNDUCHI, Raluca; Clara WEISSHAAR and Alison U. SMART (2011) "Mapping the benefits and costs associated with process innovation: the case of RFID adoption", <http://www.abdn.ac.uk/ cms152/TECH2011. pdf $>$, retrieved on February 01, 2011

CARLSEN, Jack; Janne LIBURD: Deborah EDWARDS and Paddy FORDE (2008) "Overview of Innovation for Sustainable Tourism", In CARLSEN, Jack; Janne LIBURD; Deborah EDWARDS and Paddy FORDE (editors), Innovations for Sustainable Tourism: International Case Studies, p. 3-15, BEST, Australia.

DODDS, Rachel and Jerome L. MCELROY (2008) "St. Kitts at a Crossroads". ARA Journal of Travel Research, vol. 1, n 2, p. 1-10.

FADEEVA, Zinaida (2004) "Translation of sustainability ideas in tourism networks: some roles of cross-sectoral networks in change towards sustainable development". Journal of Cleaner Production, vol. 13, nº 2, p. 175-189.

FONT, Xavier and Tor E. AHJEM (1999) "Searching for a balance in tourism development strategies". International Journal of Contemporary Hospitality Management, vol. 11, n 2/3, p. 73-77.

GRACI, Sonya and Rachel DODDS (2010) Sustainable Tourism in Island Destinations. Earthscan, London, 248 p.

HJALAGER, Anne-Mette (1996) "Tourism and the Environment: The Innovation Connection", Journal of Sustainable Tourism, vol. 4, $\mathrm{n}^{\circ}$ 4, $\mathrm{p}$. 201-218.

HJALAGER, Anne-Mette (2002) "Repairing innovation defectiveness in tourism". Tourism Management, vol. 23, n 5, p. 465-474.

HJALAGER, Anne-Mette; E.H. HUIJBENS; P. BJÖRK; S. NORDIN; A. FLAGESTAD and Ö. KNÚTSSON (2008) Innovation systems in Nordic tourism. Nordic Innovation Centre, Oslo. 72 p.

KELMAN, Ilan (2007) "Sustainable livelihoods from natural heritage on islands". Island Studies Journal, vol. 2, n 1, p. 101-114.

KERNEL, Pernille (2005) "Creating and Implementing a Model for Sustainable Development in Tourism Enterprises". Journal of Cleaner Production, vol. 13, n² 2, p. 151-164.

LIM, Charles C. and Chris COOPER (2009) "Beyond sustainability: optimising island tourism development". International Journal of Tourism Research, vol. 11, n 1 , p. 89-103.

LIU, Zhenhua (2003) "Sustainable tourism development: a critique". Journal of Sustainable Tourism, vol. 11, n ${ }^{\circ}$ 6, p. 459-475.

MARKIDES, Constantinos (2006) "Disruptive Innovation: In Need of Better Theory". Journal of Product Innovation Management, vol. 23, $\mathrm{n}^{\circ}$ 1, p. $19-25$. 
MCELROY, Jerome L. (2006) "Small Island Tourism Economies Across the Life Cycle”. Asia Pacific Viewpoint, vol. 47, n 1, p. 61-77.

NANKERVIS, Alan; Yuki MIYAMOTO; John MILTON-SMITH and Ruth TAYLOR (eds) (2005). The Management of Services, Cambridge University Press, Cambridge. 376 p.

O'CONNOR, Edward J.; Charles K. PARSONS; Robert C. LINDEN and David M. HEROLD (1990) "Implementing New Technology: Management Issues and Opportunities". Journal of High Technology Management Research, vol. 1, $\mathrm{n}^{\circ}$ 1, p. 69-89.

PASKALEVA- SHAPIRA, Krassimira; Jose AZORIN and Aline CHIABAI (2008) "Enhancing Digital Access to Local Cultural Heritage Through e-Governance: Innovations in Theory and Practice from Genoa, Italy", Innovation: The European Journal of Social Sciences, vol. 21, $\mathrm{n}^{\circ} 4$, 389- 405 .
SEARS, Greg J. and Vishwanath V. BABA (2011) “Toward a Multistage, Multilevel Theory of Innovation”. Canadian Journal of Administrative Sciences, vol. 28, $\mathrm{n}^{\circ}$ 4, p. 357- 372.

SCHAPER, Michael and Thierry VOLERY (2007) Entrepreneurship and Small Business. $2^{\text {nd }}$ Pacific Rim Edition. Wiley, Stafford, Australia, $482 \mathrm{p}$.

YU, Dan and Chang Chieh HANG (2010) "A Reflective Review of Disruptive Innovation Theory". International Journal of Management Reviews, vol. $12, \mathrm{n}^{\circ} 4, \mathrm{p} .435-452$.

WEBER, Mary Margaret and S. Prasad KANTAMNENI (2002) "POS and EDI in retailing: an examination of underlying benefits and barriers". Supply Chain Management, vol. 7, n 5, p. 311-317.

WILLIAMS, Peter W. and Ian F. PONSFORD (2009) "Confronting tourism's environmental paradox: Transitioning for sustainable tourism”. Futures, vol. 41, n 6, p. 396-404.

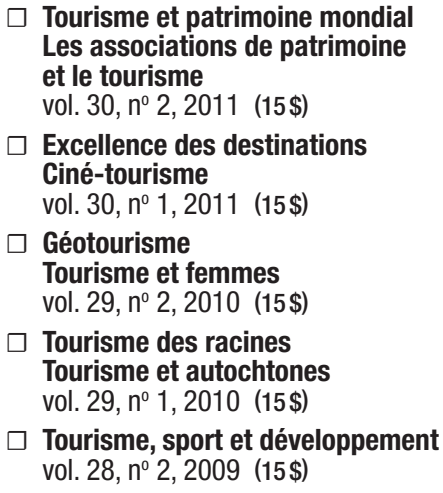

$\square$ Tourisme et patrimoine mondial Les associations de patrimoine et le tourisme vol. $30, n^{\circ} 2,2011$ (15\$)

$\square$ Excellence des destinations Ciné-tourisme vol. 30, no 1, 2011 (15\$)

$\square$ Géotourisme

Tourisme et femmes vol. 29, n $n^{0} 2,2010$ (15\$)

$\square$ Tourisme des racines Tourisme et autochtones vol. 29, n $n^{0} 1,2010$ (15\$)

$\square$ Tourisme, sport et développement vol. 28, no 2, 2009 (15\$) \\ $\square$ Tourisme polaire vol. 28, n 1, 2009 (15\$) \\ $\square$ Nouveaux musées, nouveaux tourismes vol. 27, $n^{\circ} 3$, automne 2008 (12\$) \\ $\square$ Les grands équipements touristiques vol. 27, n² 2, été 2008 (12\$) \\ $\square$ La science du tourisme vol. 27, n 1 , printemps 2008 (12\$) \\ $\square$ Tourisme et solidarité vol. 26, n $n^{\circ}$ 3, automne 2007 (12\$) \\ $\square$ Tourisme et attractivité vol. 26, n 2, été 2007 (12\$) \\ $\square$ Tourisme Caraïbe vol. $26, n^{0} 1$, printemps 2007 (12\$)}

30 ANS D'EXPÉRIENCE EN TOURISME Complétez votre collection

Retournez ce bon de commande avec votre paiement. Taxes et frais de transport en sus. $\square$ Forêt vol. $25, n^{\circ} 3$, automne 2006 (12\$)

$\square$ Désirs d'Orient vol. 25, n 2, été 2006 (12\$)

$\square$ Tourisme gourmand vol. $25, n^{0} 1$, printemps 2006 (12\$)

$\square$ Tourisme et santé vol. 24, $n^{0} 3$, automne 2005 (12\$)

$\square$ Tourisme, religion et patrimoine vol. 24, no 2, été 2005 (12\$)

$\square$ Maroc vol. 24, n ${ }^{0} 1$, printemps 2005 (12\$)

$\square$ Regards sur l'hôtellerie vol. 23, n $n^{0} 3$, automne 2004 (12\$)
Presses de l'Université du Québec, Service des abonnements Édifice Le Delta I, bureau 450, 2875, boulevard Laurier Québec (Québec) G1V 2M2, CANADA
Prénom

Adresse

Code postal

Mode de paiement :

Détenteur de la carte

Signature
Nom

Ville Province

Pays

$\square$ Chèque (à l'ordre des PUQ) Numéro de la carte

$\square$ Visa

$\square$ Master Card Date d'expiration 